\title{
On Initiation of Stall in Axial Flow Compressors
}

\author{
Jerzy A. Owczarek
}

Department of Mechanical Engineering and Mechanics, Lehigh University, Bethlehem, PA 18017, USA; jao6@lehigh.edu; Tel.: +1-610-691-5594

Academic Editor: Gerard Bois

Received: 1 November 2016; Accepted: 12 April 2017; Published: 20 April 2017

\begin{abstract}
This Technical Note calls attention to the fact that observed initiation of stall in an axial flow compressor can be explained by the pressure pulses reflecting between the stator and rotor blades. The phenomenon of reflection of pressure pulses between the rotor and stator blades of turbines was first observed in in 1965 and reported in 1966. It can occur in turbines and axial-flow compressors. Subsequently the reflecting pressure pulses were able to explain turbine and axial-flow compressor blade vibrations.
\end{abstract}

Keywords: Stall initiation in axial flow compressors; Reflecting Pressure Pulses; Reflecting Pressure Waves; Wave Reflections; Rotor-Stator Interaction

In 1994 P.B. Lawless, K.H. Kim, and S. Fleeter [1] presented results of research "directed at the identification of spatially coherent pressure waves that would serve as precursors to instability development, including both the initiation of rotating stall and rotating stall during a surge cycle, thereby extending the information on stall initiation in axial flow compressors". Their experiments were run on a three-stage axial flow compressor having 36 inlet guide vanes (IGVs, $n_{V}$ ) and 43 blades $\left(n_{B}\right)$ of the instrumented (first) rotor at $2250 \mathrm{rpm}$ (or rotor blade pass speed of $37.5 \mathrm{~Hz}$ ). They observed pressure disturbances propagating around the circumference initially at the rotational speed of $37.5 \mathrm{~Hz}$, which quickly become "adjusted" to a stall frequency of $14 \mathrm{~Hz}$. This is illustrated in Figures 5 and 10 of their paper. Their Figure 5 is reproduced below (Figure 1).

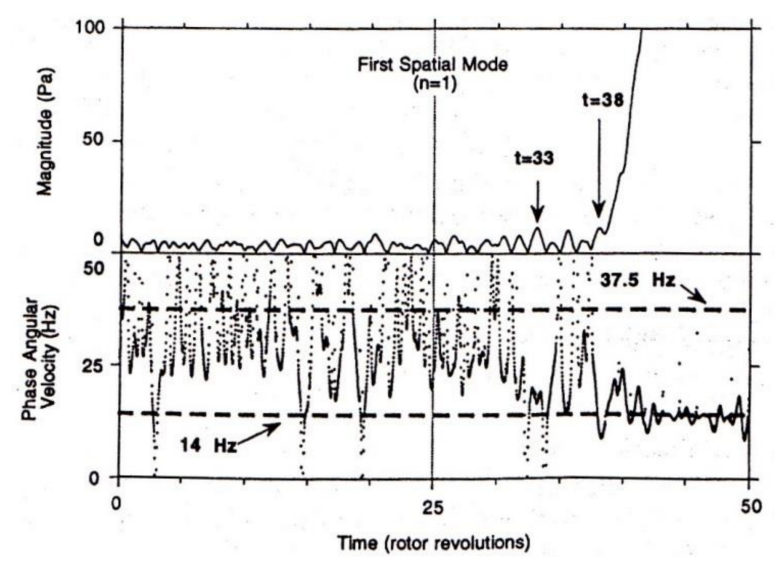

Figure 1. Rise of the first spatial mode magnitude and phase angular velocity from the first-stage microphone array. Reproduced with permission from [1].

In "Summary and Conclusions", they say that: "The transition to stall was observed to be an abrupt process, with the eruption of a stall cell on rotor blades corresponding to a strong rise in the spatial mode magnitude. However, a weak, circumferentially distorted pressure wave was detected 
that began adjusting to the ultimate phase propagation velocity of the finite stall pattern from within 5 to 26 revolutions prior to a significant rise in the mode magnitude and the indication of a stall cell from the rotor blade pressure transducers. Comparison of the first and second harmonics of this signal indicate that this disturbance is represented in the spatial domain by an impulsive-type waveform." They add that: "The impulsive nature of the weak pressure disturbance prior to stall suggests that these events represent a short length scale event in the compressor that is propagating around the annulus."

This description of the observed disturbances applies well to the reflecting pressure pulses described by the writer in references [2-7]. The ratio of the circumferential speed of propagation of the reflecting pressure pulses, $V_{W}$, to the rotor peripheral (or blade pass) speed, $W$, for the waves reflecting between the rotor blades and the upstream stator vanes is given by Equation (11) of the writer's 1992 AIAA 92-3075 paper "Wave Reflections in Subsonic Axial-Flow Turbomachines" [5].

From this equation, it follows that for the forward-running waves $(1 \mathrm{~W} \times 1 \mathrm{~V}) \mathrm{F}$ with $n_{1}=-2$ (reflections every second blade), reflecting every upstream stator vane $(n=1)$ we have:

$$
\frac{V_{w}}{W}=\frac{1}{1-\frac{n_{1} n_{v}}{n_{B}}}=\frac{1}{1-\frac{(-2) 36}{43}}=0.3739
$$

The same result is obtained for the backward-running wave $(1 \mathrm{~W} \times 1 \mathrm{~V}) \mathrm{B}$ with $n_{1}=2$.

Lawless, Kim, and Fleeter observed a (stall speed)/(rotor blade pass speed) ratio of $14 / 37.5=0.3733$, which is almost identical to the ratio $V_{W} / W$ obtained for the $(1 \mathrm{~W} \times 1 \mathrm{~V}) \mathrm{F}$ and $(1 \mathrm{~W} \times 1 \mathrm{~V}) \mathrm{B}$ waves.

This finding shows that the circumferential ("adjusted" ultimate) speed of the pressure disturbances, or stall speed, observed by Lawless, Kim, and Fleeter is the same as the calculated circumferential speed of the reflecting pressure waves (pulses), and as a result, is a strong indication that the observed rotating stall was initiated and driven by the reflecting pressure waves. That is, that the pressure disturbances observed by Lawless, Kim, and Fleeter were in fact the reflecting pressure pulses. This agrees with the expectations expressed in Section 1.6 on page 10 of the writer's 1992 paper [5]. Whether it is the forward- or the backward-running waves that were observed in the compressor tests by Lawless, Kim, and Fleeter could be determined from the knowledge of the shape of the IGV vanes and of the Mach number at their exit.

Conflicts of Interest: The author declares no conflict of interest.

\section{References}

1. Lawless, P.B.; Kim, K.H.; Fleeter, S. Characterization of Abrupt Rotating Stall Initiation in an Axial Flow Compressor. J. Propuls. Power 1994, 10, 709-715. [CrossRef]

2. Owczarek, J.A. On a Wave Phenomenon in Turbines. J. Eng. Power 1966, 88, 262-276. [CrossRef]

3. Owczarek, J.A. Analysis of an Axial Compressor Blade Vibration Based on Wave Reflection Theory. J. Eng. Gas Turbines Power 1984, 106, 57-64. [CrossRef]

4. Owczarek, J.A. Erratum: Analysis of an Axial Compressor Blade Vibration Based on Wave Reflection Theory. J. Eng. Gas Turbines Power 1984, 106, 919. [CrossRef]

5. Owczarek, J.A. Wave Reflections in Subsonic Axial Flow Turbo-Machines. In Proceedings of the AIAA/SAE/ASME/ASEE 28th Joint Propulsion Conference and Exhibit, Nashville, TN, USA, 6-8 July 1992; Paper No. 92-3075.

6. Owczarek, J.A. On the Phenomenon of Pressure Pulses Reflecting Between Blades of Adjacent Blade Rows of Turbo-machines. J. Turbomach. 2011, 133, 021016. [CrossRef]

7. Owczarek, J.A. Erratum: On the Phenomenon of Pressure Pulses Reflecting Between Blades of Adjacent Blade Rows of Turbo-machines. J. Turbomach. 2012, 135, 0270011.

(C) 2017 by the author. Licensee MDPI, Basel, Switzerland. This article is an open access article distributed under the terms and conditions of the Creative Commons Attribution (CC BY NC ND) license (https://creativecommons.org/licenses/by-nc-nd/4.0/). 